\title{
Ebelik Alanındaki Yüksek Lisans Tezlerinin Bibliyometrik Analizi
}

Bibliometric Analysis of Master Thesis in The Subject of Midwifery

\author{
Hacer YALNIZ DİLCEN ${ }^{1}$, Filiz KANTEK ${ }^{2}$
}

\section{ÖZ}

Ebelik mesleğinin gelişimi ve bilgi kütlesinin oluşturulmasında ebelik yüksek lisans programları önemli bir role sahiptir. Bu araştırmada, Türkiye'de ebelik alanında yüksek lisans tezleri ile üretilen bilgi kütlesinin özellikleri ve gelişimsel sürecinin incelenmesi amaçlanmıştır.

Bibliyometrik analiz gerçekleştirilen araştırmada 2004 ve 2016 yılları arasında ebelik anabilim dalında yürütülen 126 yüksek lisans tezi incelenmiştir. Verilerin analizinde Microsoft Excel, UCINET ve Netdraw programları kullanılmıştır.

Tezlerin \%68,2'sinin (86 tez) 2012-2016 y1lları arasında üretildiği ve en fazla tezin $2014(\mathrm{n}=28)$ yılında üretildiği, \%65,07'sinin danışmanının doktor öğretim üyesi unvanına sahip olduğu belirlenmiştir. Tezlerin çoğunlukla tanımlayıcı araştırma tasarımına sahip olduğu, gebe örnekleminde gerçekleştirildiği, veri toplama aracı olarak ölçek ve anketlerin kullanıldığ 1 saptanmıştır. En sık kullanılan anahtar kelimelerin "Kaygı", "Eğitim”, "Ebeler", “Ebelik", "Gebelik" kelimeleri üzerinde yoğunlaştığ1 görülmüştür.

Yillar içerisinde ebelik yüksek lisans tezlerinin ve ebelik bölümlerinin sayısında önemli bir artış olmuştur. Tanımlayıcı tasarıma sahip tezlerin sayısının fazla olması ve konu olarak benzer alanlarda yoğunluğunun olmaması bu alanda daha fazla araştırmaya ihtiyaç olduğunu göstermektedir. Ebelik lisansüstü programlarının sayısının artırılması ebelik bilgi kütlesinin ve akademik insan gücünün artmasını sağlayarak bu alanın gelişimine önemli katkı sağlayacaktır.

Anahtar Kelimeler: Ebelik Eğitimi, Bibliyometrik Analiz, Yüksek Lisans, Tez.

\begin{abstract}
Midwifery graduate programs play an important role in the development of the midwifery profession and for the formation of the mass of knowledge. The aim is to examine the characteristics and the developmental process of mass knowledge in Turkey produced by master theses in midwifery.

Bibliometric analysis in this research, 126 master's thesis in midwifery disciplinary, were examined between 2004 and 2016. To analyze the data, Microsoft Excel, UCINET and Netdraw programs were used.

It was determined that, $68.2 \%$ of the theses (86 theses) were produced between the years 2012-2016, and the most thesis were produced in $2014(\mathrm{n}=28)$ and that $65.07 \%$ of them had advisor in PhD Degree. It was determined that, theses had mostly descriptive research design, carried out in the pregnant sample, and that scale and questionnaires were used as data collection tools. It has been seen that the most commonly used keywords were focused on "Anxiety", "Training", "Midwifes", "Midwifery" and "Pregnancy".

Over the years, there has been a significant increase in the number of midwifery master theses and universities. The fact that the thesis with a descriptive design is intense and that there is no intensity in the subject, shows that more research is needed in this area. Increasing the number of midwifery graduate programs, will provide an important contribution to the development of this field by increasing the midwifery information mas number and academic manpower.
\end{abstract}

Keywords: Midwifery Education, Bibliometric Analysis, Master's Degree, Thesis.

* Bu çalışma 07-09 Kasım 2018 tarihlerinde İzmir'de gerçekleştirilmiş olan 1. Uluslararası Ebelik Eğitim Araştırma Geliştirme (EBEARGE) Kongresi'ne sözel bildiri olarak sunulmuștur.

${ }^{1}$ Dr Öğretim Üyesi, Ebelik, Bartın Üniversitesi, Sağlık Bilimler Fakültesi, hdilcen@bartin.edu.tr, ORCID:0000-0001-5911-7201

${ }^{2}$ Doç. Dr., Hemşirelik Yönetimi, Akdeniz Üniversitesi, Hemşirelik Fakültesi, fkantek@akdeniz.edu.tr, ORCID:0000-0002-1524-9824 


\section{GİRISS}

Ebelik insanlık tarihi kadar eski bir meslek olmakla birlikte, profesyonel ebelik, Türkiye'de nispeten yeni bir bilimsel alandır. ${ }^{1}$ Günümüzde ebelik, bilim, sanat, etik değerler içeren profesyonel bir disiplin olarak tanımlanmaktadır. ${ }^{2}$ Profesyonellik mesleğe ilişkin standartların oluşturulması ve kaliteli bakım verilmesinde son derece önemlidir. ${ }^{3}$ Eğitim süresi, yasal düzenlemeler, etik kodlar, örgütlenme, otonomi, araştırma ve topluma hizmet sunma ebelerin mesleki profesyonelliğinin belirleyicisidir. $^{4} \quad \mathrm{Bu}$ nedenle, profesyonel ebelik mesleği için ebelik alanında üretilen bilimsel bilgi ve ebelik eğitim süreci önem taşımaktadır.

Türkiye'de ebelik eğitimi 1996 yılına kadar ilkokul, lise ve ön lisans gibi farklı düzeylerde devam etmiştir. Avrupa Birliği'nin eğitim standartlarına uyum amacıyla, 1996 yılında ebelik eğitimi 4 yıllık lisans programlarına dönüștürülmüștür. 1997 yılında çeşitli üniversitelerde 28 sağlık yüksekokulunda ilk lisans düzeyinde ebelik öğrencileri eğitime başlamıştır. ${ }^{5}$ Türkiye'de halen Sağlık Bilimleri Fakültesi ve Sağlık Yüksekokullarında 39 ebelik bölümü bulunmaktadır. Ebelik eğitiminde ilk yüksek lisans programı 2003 yılında açılmış ve bunu 2013 yılında doktora programı izlemiştir. Halen Atatürk Üniversitesi, Adnan Menderes, Celal Bayar, Cumhuriyet, Çukurova, Ege, İstanbul, Kocaeli, Karabük ve Mersin Üniversitesi olmak üzere 14 üniversitede Sağlık Bilimleri Enstitüleri bünyesindeki Ebelik Anabilim Dallarında yüksek lisans programı bulunmaktadır. ${ }^{1,5-7}$ Atatürk Üniversitesi, Adnan Menderes, Ege, İstanbul, Osmangazi, Celal Bayar, Kafkas üniversitelerinde doktora eğitimi verilmektedir. ${ }^{8}$ Dünyada birçok üniversitede ebelikte yüksek lisans programları var olmasına karşın, ebelikte doktora programları sadece Türkiye, Avustralya, İngiltere, Meksika, Norveç ve Yeni Zelanda'da bulunmaktadır. ${ }^{9}$

Ebelik lisansüstü programları ile mesleki bilgi ve beceri birikime sahip, ihtiyacı olan bilgiye ulaşabilen, etik ilkeler çerçevesinde bilgi çözümleyebilen, uygulayabilen, başkalarıyla paylaşabilen, bilimsel araştırma yaparak bilimsel bilgi üretimini yapabilen ve ürettiği bilgi kütlesini uygulamalarında kullanabilen profesyonel ebeler yetiştirilmektedir. ${ }^{8,10}$ Lisansüstü programlar profesyonel meslek üyesi yetiştirmenin yanı sira bu programlarda üretilen tezler ile mesleki bilgi birikimine önemli katkılar sağlamaktadır. ${ }^{1,10} \mathrm{Bu}$ nedenle, ebelik lisansüstü programları ebelik mesleğinin profesyonelleşmesinin vazgeçilmez unsurlarından biridir. ${ }^{11}$

Bibliyometrik analiz, belirli bir alandaki bilgi üretim yapısını belirlemek amacıyla son yıllarda yayın olarak kullanılan nicel bir yöntem dir. ${ }^{12} \mathrm{Bu}$ yöntem yaygın olarak belirli konuları, kitapları, dergileri, tezleri ve diğer yayınları analiz etmek için kullanılmaktadır. Bibliyometrik analiz, literatürdeki farklı kalıpları tanımlayabilmekte, alandaki en üretken yazarları, kurumları, ülkeleri ve dergileri, zaman içinde bilimsel üretim oranlarını, atıfta bulunulan çalışmaları ve yazarlar arasındaki iletişim ve işbirliği modellerini ortaya koymaya olanak sağlamaktadır. ${ }^{12}$ Çalışma sonuçlarının gelecek araştırma stratejilerinin geliştirilmesi için bilgi temeli oluşturması bu yöntemin en büyük yararlarından biridir. $^{13}$ Ulusal literatürde bibliyometrik analiz yönteminin yaygın olarak sosyal bilimler alanında ve sınırlı olarak sağlık bilimleri alanında kullanıldığı görülmektedir. ${ }^{14} \mathrm{Bu}$ çalıșmalarda bibliyometrik analiz kullanılarak tezler ${ }^{15,16}$, belirli bir alan ${ }^{17-19}$ ve dergiler ${ }^{20-24}$ incelenmiștir.

Literatür incelendiğinde Türkiye'de ebelik alanına ilişkin bibliyometrik çalışmaya rastlanmamıştır. Araştırmada Türkiye'de ebelik alanında yüksek lisans tezleri ile üretilen bilgi kütlesinin özellikleri ve gelişimsel sürecinin incelenmesi amaçlanmıştır. Çalışma sonuçları ebelik alanında yapılan yüksek lisans tezlerinin özelliklerine ilişkin mevcut durumu ortaya koyarak, araştırma stratejilerinin geliştirilmesinde ebelik alanındaki öğretim elemanları, lisansüstü ebelik öğrencileri ve 
ebelik alanına ilişkin karar vericiler için referans oluşturacağ1 düşünülmektedir.

\section{MATERYAL VE METOT}

\section{Araştırmanın Tipi}

Araştırma tipi bibliyometrik analiz incelemesidir.

\section{Araştırmanın Evreni ve Örneklemi}

Ebelik alanındaki yüksek lisans tezlerine Yükseköğretim Kurulu'nun (YÖK) Ulusal Tez Merkezinden ulaşılmıştır. Tezlere ulaşmak için tez merkezi detaylı tarama ekranından anabilim dalı bölümünde ebelik ve tez türü bölümünde yüksek lisans seçilmiştir. Ayrıca 2017 yılına kadar tüm çalışmalara ulaşmak hedeflendiğinden tarih bölümüne 2004 ve 2016 yılları girilmiştir. Veri taraması Temmuz 2017'de yapılmıştır. Tarama sonucunda 126 yüksek lisans tezine ulaşılmıştır. Ulaşılan tezlerin ebelik anabilim dalına ait olup olmadığ tarafindan ayrı ayrı kontrol edilmiş ve tamamının ebelik anabilim dalına ait olduğu belirlenmiştir. Bu tezlerden 24'ünün kullanım izni olmadığı için özetlerine ulaşılmıştır. Araştırma için gerekli verileri içerdiği için tez özetleri araştırmaya dahil edilmiştir. Analizler 126 tez üzerinden yapılmıştır.

\section{Veri Toplama Araci}

Çalışma verilerini toplamak için araştırmacılar tarafından literatür incelenerek geliştirilen, 12 maddeden oluşan veri formu kullanılmıştır. Veri kodlama formuna her tezin yazarı, başlığı, yılı, üniversitesi, danışman unvanı, anahtar kelimeleri, araştırma tasarımı, veri toplama araçları, çalışma örneklemi, araştırmanın yapıldığ yerler ve izin durumu kodlanmıştır. Kodlanan verilerin doğruluğu araştırmacılar tarafından kontrol edilmiştir. Kodlama hatası olmadığına karar verilmiştir.

\section{İstatistiksel Değerlendirmesi}

Verilerin analizinde Microsoft Excel, verilerin görselleştirilmesinde UCINET ve Netdraw programları kullanılmıştır. Verilerin istatistiksel analizinde sayı ve yüzde dağılımı kullanılmıştır.

\section{Araştırmanın Etik Yönü}

Araştırmada literatür taraması modeli kullanıldığından doğrudan insan veya hayvanlar üzerinde bir etkisi olmamaktadır. $\mathrm{Bu}$ nedenle etik kurul onay kararına gereksinim bulunmamaktadır.

\section{Araştırmanın Sınırlılıkları}

Çalışma sonuçları tarama yapılan tarihte Yükseköğretim Kurulu tez merkezinde kayıttı yüksek lisans tez çalışmaları ile sınırlıdır.

\section{BULGULAR VE TARTIŞMA}

Tarama sonucunda 2004-2016 y1llar1 arasında tamamlanmış 126 yüksek lisans tezine ulaşılmıştır.

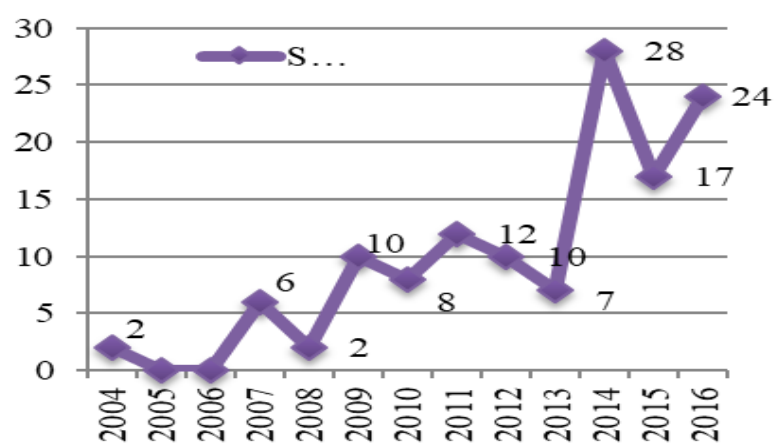

Şekil 1.Yüksek Lisans tezlerinin yapıldığı yıllara göre dağılımı (n:126)
Yıllara göre tez sayıları incelendiğinde (Şekil 1), ilk tezin üretildiği 2004 yılında iki tez üretilmiş iken bu sayının 2016 yılında 24 olduğu görülmüştür. Ayrıca tezlerin $\% 68,2$ 'sinin (86 tez) 2012-2016 y1lları arasında üretildiği ve en fazla tezin 2014 yılında $\quad(n=28)$ üretildiği belirlenmiştir. Yüksek lisans tezlerinin yapıldığı yıllara göre dağılımı Şekil 1'de, yüksek lisans tezlerinin izin durumu, danışmanların unvanları ve alanlarının dağılımı Tablo 1'de verilmiştir. 
üretken üniversiteler olduğu belirlenmiştir.

Tablo 1. Yüksek Lisans Tezlerinin İzin Durumu, Danışmanların Unvanları ve Alanlarının Dağılımı

\begin{tabular}{lrr}
\hline Tezlerin İzin Durumu & Sayı & $\%$ \\
\hline İzinli & 102 & 80,95 \\
İzinsiz & 24 & 19,04 \\
\hline Danışmanların Unvanları & & \\
\hline Profesör & 14 & 11,11 \\
Doçent & 30 & 23,80 \\
Dr Öğretim Üyesi & 82 & 65,07 \\
\hline Tez Danışmanlarının Alanı* & & \\
\hline Ebelik & 00 & 00,00 \\
Hemşirelik & 44 & 74,57 \\
Tıp & 14 & 23,71 \\
İşletme & 1 & 1,72 \\
\hline *Doktora eğitim alanlarına göre sinıflanmıştır. &
\end{tabular}

Tablo 1'e göre tezlerden \%80,95'inin kullanım iznine sahip olduğu belirlenmiştir. Ayrıca tez danışmanlarının \%65,07'sinin doktor öğretim üyesi, \%23,80'nin doçent ve $\% 11,11$ 'inin profesör olduğu saptanmıştır. Tez danışmanlarının alanı incelendiğinde, öğretim üyelerinin 8'inin ebelik lisans eğitimi olmakla birlikte ebelik alanında doktora eğitimine sahip öğretim üyesinin olmadığ 1 ve ebelik lisans eğitimine sahip olanların ise hemşirelik alanında doktora yaptığı belirlenmiştir. Ayrıca danışmanların $\% 74,57$ 'sinin hemşirelik ve \%23,71'inin tıp alanında doktora eğitimine sahip olduğu saptanmıştır. Yüksek lisans tezlerinin üretildiği üniversitelere göre dağglımı Tablo 2'de verilmiştir.

Tablo 2. Yüksek Lisans Tezlerinin Üretildiği Üniversitelere Göre Dağılımı

\begin{tabular}{lrr}
\hline Üniversiteler & Say1 & $\%$ \\
\hline Ege Üniversitesi & 28 & 22,22 \\
Cumhuriyet Üniversitesi & 22 & 17,46 \\
İstanbul Üniversitesi & 16 & 12,69 \\
Atatürk Üniversitesi & 14 & 11,11 \\
Adnan Menderes Üniversitesi & 13 & 10,31 \\
Mersin Üniversitesi & 12 & 9,52 \\
Çukurova Üniversitesi & 9 & 7,14 \\
Karabük Üniversitesi & 6 & 4,76 \\
Celal Bayar Üniversitesi & 4 & 3,17 \\
İnönü Üniversitesi & 2 & 1,58 \\
\hline
\end{tabular}

Tezlerin üretildiği üniversiteler incelendiğinde (Tablo 2), tezlerin 10 farklı üniversite tarafından üretildiği ve 28 tez ile $(\% 22,2)$ Ege Üniversitesi, 22 tez ile $(\% 17,4)$ Cumhuriyet Üniversitesi ve 16 tez ile $(\% 12,69)$ İstanbul Üniversitesi'nin en
Yüksek lisans tezlerinin yöntemsel özelliklerinin dağılımı Tablo 3'te verilmiştir.

Tablo 3. Yüksek Lisans Tezlerinin Yöntemsel Özelliklerinin Dağılımı

\begin{tabular}{|c|c|c|}
\hline Araştırmanın tipi & Say1 & $\%$ \\
\hline Tanımlayıcı & 83 & 65,91 \\
\hline Vaka Kontrol & 21 & 16,66 \\
\hline Metodolojik & 10 & 7,93 \\
\hline Deneysel & 8 & 6,34 \\
\hline Prospektif Kohort & 2 & 1,58 \\
\hline Niteliksel & 2 & 1,58 \\
\hline \multicolumn{3}{|c|}{ Tezlerin Veri Toplama Araçları } \\
\hline Ölçek & 96 & 76,19 \\
\hline Anket & 21 & 16,66 \\
\hline Soru formu & 8 & 6,34 \\
\hline Diğer & 1 & 0,79 \\
\hline \multicolumn{3}{|l|}{ Örneklem Seçimi } \\
\hline Gebe & 39 & 28,67 \\
\hline Anne & 25 & 18,38 \\
\hline Kadın & 21 & 15,44 \\
\hline Ebe & 14 & 10,29 \\
\hline Lohusa & 7 & 5,14 \\
\hline Öğrenci & 5 & 3,67 \\
\hline Hasta & 5 & 3,67 \\
\hline Bebek & 5 & 3,67 \\
\hline Baba & 4 & 3,17 \\
\hline Hemşire & 3 & 2,20 \\
\hline Doktor & 3 & 2,20 \\
\hline Ebeveyn & 2 & 1,47 \\
\hline Öğretim üyesi & 1 & 0,73 \\
\hline Hasta yakını & 1 & 0,73 \\
\hline Diğger & 1 & 0,73 \\
\hline \multicolumn{3}{|l|}{ Örneklem Sayısı } \\
\hline 50 ve altı & 6 & 4,76 \\
\hline $51-100$ arasi & 28 & 22,22 \\
\hline $101-250$ aras 1 & 39 & 30,95 \\
\hline 251-500 aras1 & 40 & 31,74 \\
\hline $501-1000$ aras1 & 8 & 6,34 \\
\hline 1001 ve üzeri & 4 & 3,17 \\
\hline Ulaşılamayan & 1 & 0,79 \\
\hline \multicolumn{3}{|c|}{ Tezlerin Uygulama Alanları } \\
\hline Hastane & 86 & 68,25 \\
\hline Sağl1k ocağ1/ASM & 19 & 15,07 \\
\hline Doğumevi & 10 & 0,79 \\
\hline Ev & 4 & 3,17 \\
\hline
\end{tabular}

Tezlerin araştırma tasarımları incelendiğinde tezlerde tanımlayıcı, vaka kontrol, metodolojik, kohort, deneysel ve nitel olmak üzere altı farklı araştırma tasarımının kullanıldığı belirlenmiştir. Tanımlayıcı araştırma tasarımı $(\mathrm{n}=83$, $\% 63,91$ ) en fazla kullanılan tasarım iken nitel araştırma $(n=2, \% 1,58)$ tasarımının en az kullanılan tasarım olduğu saptanmıştır. 
Tezlerde en sık ölçek $(\% 76,19)$ ve anketlerin $(\% 16,66)$ veri toplama arac1 olarak kullanıldığı, \%31,74'ünün örneklem sayısının 251-500 arasında olduğu, örneklemi çoğunlukla \%28,67 ile gebelerin oluşturduğu ve çalışma ortamı olarak \%68,25 ile hastanelerin seçildiği belirlenmiştir.

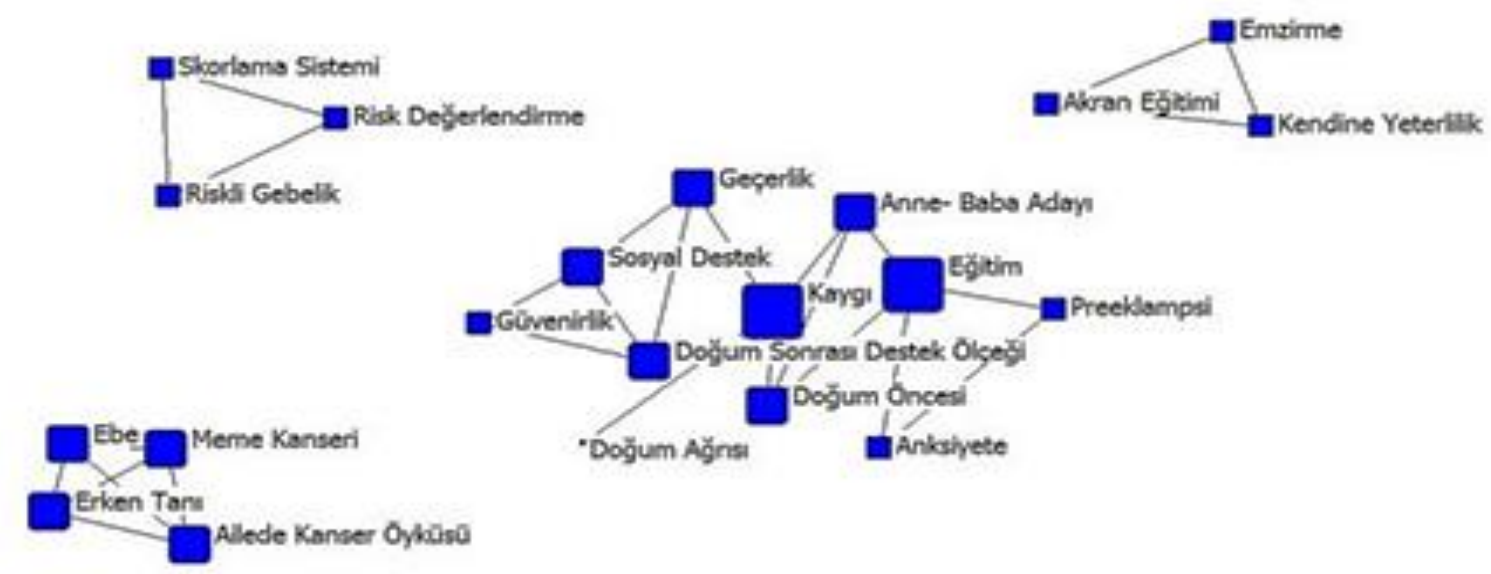

Şekil 2. 2004-2007 Yıllarına Ait Tezlerin Anahtar Kelime Ağı

Tezlerde belirtilen anahtar kelimelerin yıllara göre dağılımı incelendiğinde, 20042007 yılları arasında 8 çalışmada 23 adet, 2008-2011 yılları arasında 32 çalışmada 127 adet, 2012-2016 yılları arasında 86 çalışmada 194 adet anahtar kelime kullanıldığ tespit edilmiştir.

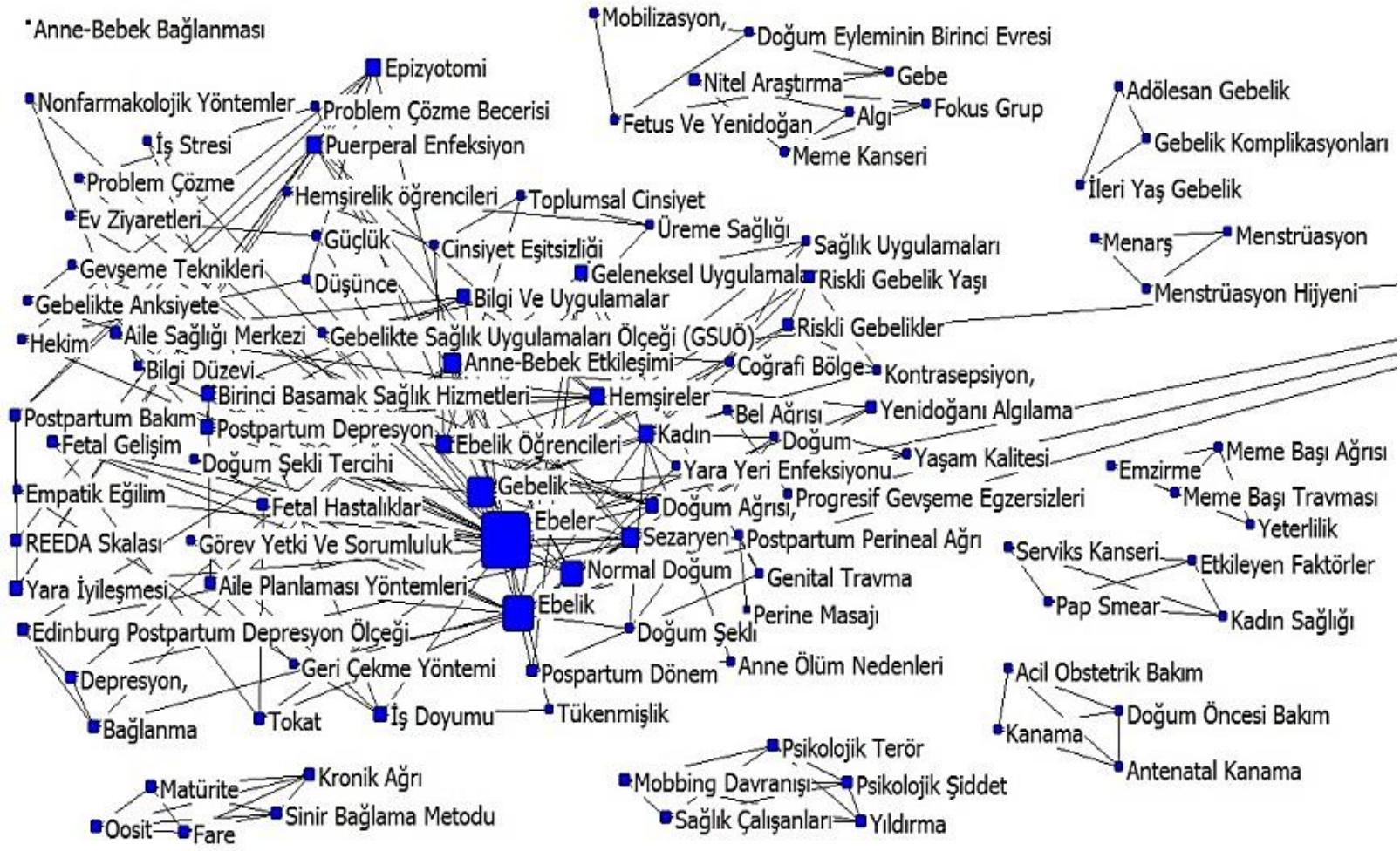

Şekil 3. 2008-2011 Tezlerin Anahtar Kelime Ăgı

Tezlerin anahtar kelime ağı Şekil 2'de, 2008-2011 y1llarina ait tezlerin anahtar kelime ağı Şekil 3'de, 2012-2016 yıllarına ait tezlerin anahtar kelime ağı Şekil 4'te verilmiştir. 


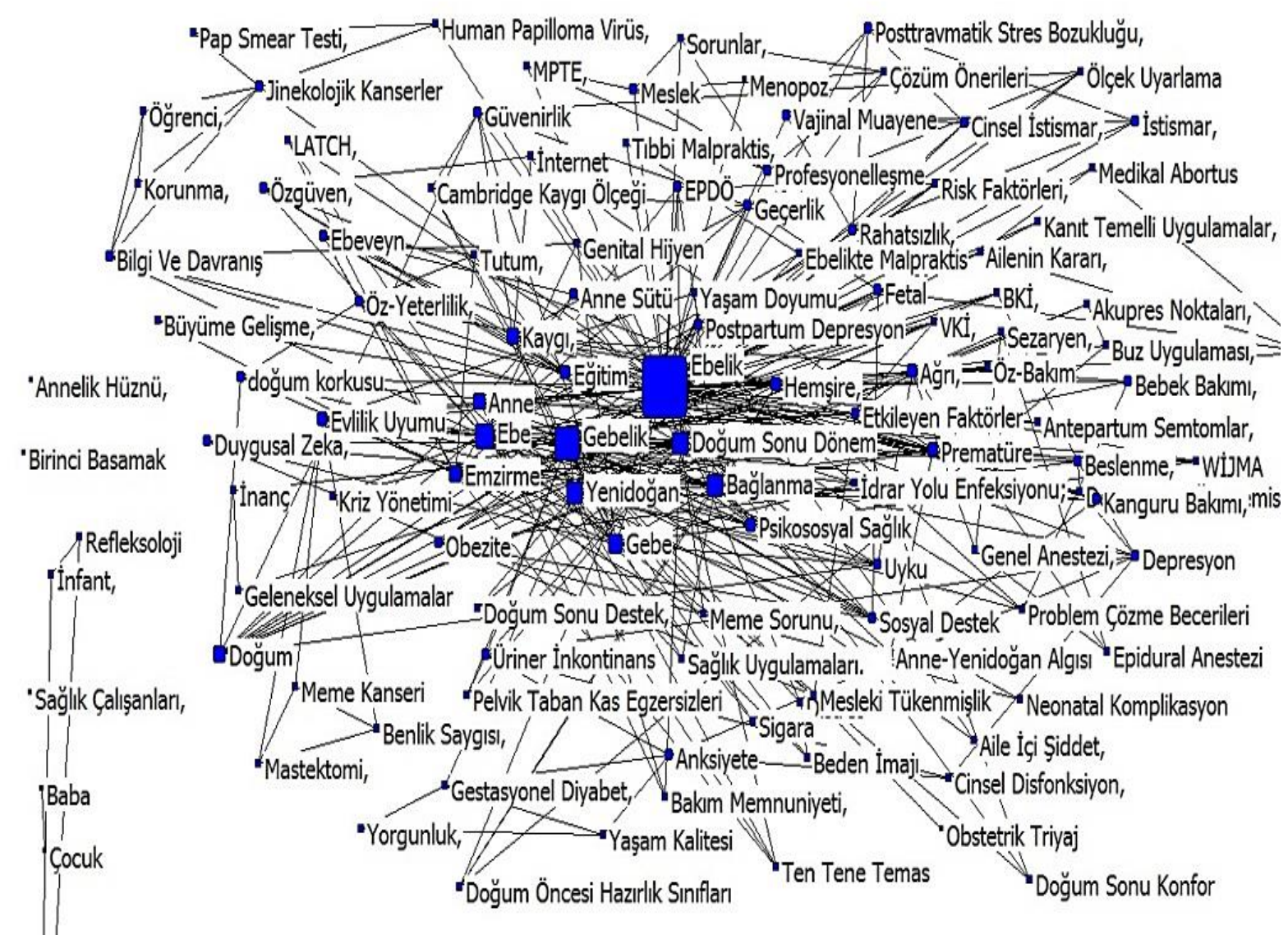

Şekil 4. 2012-2016 Tezlerin Anahtar Kelime Ăğ

Tezlerde kullanilan ortak anahtar kelimeleri belirlemek için sosyal ağ analizi kullanılmıştır. UCINET programı ile görselleştirilen ortak kelime ağ Şekil 1-2-3'te verilmiştir. Anahtar kelime ağları incelendiğinde, en sık kullanılan anahtar kelimelerin 2004-2007 y1llar1 arasında "kaygı" ve "eğitim", 2008-2011 y1lları arasinda "ebeler", "ebelik", "gebelik", 20122016 yılları arasında "ebelik", "gebelik" olduğu belirlenmiştir.

Araştırmada 2004-2016 yılları arasında ebelik yüksek lisans programlarında üretilen 126 yüksek lisans tezi incelenmiştir. Bulgularımız tez sayısının 2004 yılında 2 iken, 2016 yılında 24'e ulaştığını ve düzenli olmamakla birlikte yillar içerisinde tez sayılarında artış olduğunu ortaya koymuştur. Tez sayılarındaki bu artış 2003 yılından itibaren ebelik yüksek lisans program ve öğrenci sayısındaki artışa bağlı olabilir. Nitekim 2019 Şubat ayı itibarıyla tez sayısının 219 olması bu bulgumuzu desteklemektedir.
Tez çalışması sürecinde öğrencinin alanın uzmanı bir öğretim üyesinden alacağ danışmanlık tezin kalitesini etkiyen önemli unsurlardan biridir. ${ }^{25}$ Ülkemizde ilk ebelik doktora programı 2013 yılında açılmış ve ilk mezunlarını 2017 yılında vermiştir. ${ }^{11} \mathrm{Bu}$ nedenle ebelik alanında sınırlı sayıda öğretim üyesi bulunmaktadır. Bu tarihe kadar ebeler öncelikle hemşirelik alanında olmak üzere farklı bilim alanlarında lisansüstü eğitim almışlardır. ${ }^{1} \mathrm{Bu}$ nedenle ülkemizdeki ebelik lisansüstü eğitiminin hemşirelik alanının desteği ile geliştiği söylenebilir. Araştırmamızda danışmanların tamamının ebelik alanının dışında olması ve $\% 65,07$ 'sinin doktor öğretim üyesi unvanına sahip olması ebelik alanın gelişim sürecinde olduğunun göstergesi olarak düşünülebilir.

Tezlerin üretildiği üniversiteler incelendiğinde, tezlerin 10 farklı üniversite tarafından üretildiği ve 28 tez ile $(\% 22,2)$ Ege Üniversitesi, 22 tez ile $(\% 17,4)$ Cumhuriyet Üniversitesi ve 16 tez ile $(\% 12,69)$ İstanbul Üniversitesinin en üretken üniversiteler olduğu belirlenmiştir. 
En üretken üniversitelerin ortak özelliği onların ebelik yüksek lisans eğitimi vermeye başlayan ilk üniversiteler olmasıdır. ${ }^{1}$ Yıllar içerisinde bu üniversitelerin diğerlerine göre daha fazla tez üretmeleri beklendik bir durum olmakla birlikte, ülkemizdeki ebelik programlarının sayısı dikkate alındığında, araştırmamızda tezlerin sadece on farklı üniversite tarafından üretildiğinin belirlenmesi, ebelik yüksek lisans programlarının sayısal olarak yetersiz olduğunu göstermesi açısından dikkat çekici bir bulgu olduğu düşünülebilir.

Bir araştırmanın yöntemi araştırmanın en önemli bölümüdür ve çatısını oluşturmaktadır. ${ }^{26}$ Tezlerin araştırma yöntemleri incelendiğinde, yarıdan fazlasının tanımlayıcı araştırma tasarımına sahip olduğu ve veri toplama aracı olarak ölçek ve anketlerin kullanıldığ 1 belirlenmiştir. Ülkemizde çeşitli alanlarda üretilen tezleri inceleyen önceki çalışmalarda yüksek lisans tezlerinde yoğun olarak tanımlayıcı araştırma tasarımı kullanıldığ 1 belirlenirken, ${ }^{28,29}$ doktora tezlerinde bu oranın daha düşük olduğu ve deneysel araştırma tasarımı kullanımın arttığ1 görülmektedir. ${ }^{25,30-31}$ Yüksek lisans eğitimi bir yıl teorik ve bir yıl tez olmak üzere toplam iki yıllık eğitim sürecini kapsamaktadır. ${ }^{32}$ Tez çalışmaları için bir yıllık sinırlı zamanın olması tezlerde tanımlayıcı araștırma tasarımın tercihinin bir nedeni olabilir. Doktora tezlerinde tanımlayıcı araştırma tasarımı seçiminin azalması bu görüşümüzü desteklemektedir. Ayrıca tezlerde veri toplama aracı olarak yoğun olarak ölçek ve anketlerin kullanılması, tanımlayıcı araştırma tasarımının kullanılmasının beklendik bir sonucu olabilir.

Araştırmada tezlerin en sık gebe örnekleminde ve hastane ortaminda gerçekleştirildiği belirlenmiştir. Doğum öncesi, doğum ve doğum sonras1 dönemlerinde annelere gerekli izlemi yapma, bakım verme ve önerilerde bulunma ebelerin önemli rollerindendir. ${ }^{2}$ Tezlerde ebelik alanına uygun olarak, daha çok gebe örnekleminin kullanması tezlerin daha çok doğum öncesi döneme odaklandığını göstermesi açısından pozitif bir bulgu olarak değerlendirilebilir.

Anahtar kelimelerin analizi araştırmalarda incelenen konular hakkında bilgi vericidir. Bulgularımı 2004-2016 y1lları arasinda üretilen 216 tezde toplam 344 anahtar kelime kullanıldığını ve anahtar kelimelerin "Kaygı", "Eğitim", "Ebeler", "Ebelik", "Gebelik" gibi sınırlı sayıdaki kelimelere yoğunlaştığını göstermiştir. $\mathrm{Bu}$ sonuca dayanarak ebelik yüksek lisans tez konularının program amaçları ile uyumlu olduğu söylenebilir. Ebelik yüksek lisans programlarının amacı; ulusal ve uluslararası alanda anne ve yeni doğan sağlığını koruma ve geliştirmede rolü olan ebelerin, gerekli bilgi ve beceri birikimini elde edebilmesini sağlamak olarak tanımlanmaktadır. ${ }^{32}$ Ebelik alanındaki tezlerdeki sayısal artış anahtar kelime sayısında ve aynı konularda yoğunlaşmasına katkı sağlayacaktır. Araştırmamızda 20042008, 2009-2011 ve 2012-2016 yillar1 arasındaki anahtar kelime sayısı ve kelime yoğunluğun artmasının bu bulgumuzu desteklediği söylenebilir.

\section{SONUC VE ÖNERILER}

Sonuç olarak bu çalıșmada, yıllar içerisinde ebelik yüksek lisans tezlerinin ve üniversitelerin sayısında önemli bir artış olduğu görülmektedir. Tez sayısında artış olumlu bir sonuç olmakla birlikte, tanımlayıcı tasarıma sahip tezlerin sayısının fazla olması ve benzer konularda tez çalışmaların olmaması bu alanda daha fazla araștırmaya ihtiyaç olduğunu göstermesi açısından önemlidir. Ebelik lisansüstü programlarının sayısının artırılması ebelik bilgi kütlesinin ve akademik insan gücünün artmasını sağlayarak bu alanın gelişimine önemli katkı sağlayacaktır. 


\section{KAYNAKLAR}

1. Yücel, Ü., Ekșioğlu, A., Demirelöz, M., Akmeșe, Z. B. Koçak, Y. Ç., Soğukpınar, N. (2013). Profile Analysis of Post Graduateeducation of Midwifery in Turkey. Int J Hum Sci, 10 (1), 1342-54

2. Arslan, H., Karahan, N., Çam, Ç. (2008). Ebeliğin Doğası ve Doğum Şekli Üzerine Etkisi. Maltepe Üniversitesi Hemşirelik Bilim ve Sanatı Dergisi, 4 (2), 30-36.

3. Demir, D. Y., Yönder, M., Yorgun, S., Yıldırım, U. Y., Umur S., Aytekin A. (2014). Hemşirelerin Profesyonel Tutumları ile Bunu Etkileyen Faktörlerin İncelenmesi. Anadolu Hemșirelik ve Sağlık Bilimleri Dergisi, 17 (3), 158-64.

4. Ergin, A., Özcan, Ş. M., Acar, Z., Ersoy, N., Karahan, N (2013). Determination Of National Midwifery Ethical Values And Ethical Codes: In Turkey, Nursing Ethics, 20 (7), 808- 18 .

5. Sogukpinar, N., Saydam, B. K., Bozkurt, Ö. D., Öztürk, H., Pelik, A. (2007). Past and Present Midwifery Education in Turkey. Midwifery, 23 (4), 433-42. Doi: 10.1016/j.midw.2007.01.011.

6. Yıldırım, G., Koçkanat, P. \& Duran, Ö. (2014). Ulusal Ebelik Kodları ve Meslek Değerleri. Sürekli Tıp Eğitim Dergisi, 23 (4), 148-54.

7. Bayındır, Ü. \& Durak, H. İ. (2008). Türkiye'de Ebe İnsan Gücü. Türkiye'de Tıp-Sağlık Bilimleri Alanında Eğitim ve İnsan Gücü Planlaması "Mevcut Durum ve 2013 yılı Vizyonu", Üniversitelerarası Kurul Tıp-Sağlık Bilimleri Eğitim Konseyi Başkanlığı Yayınları, Birinci Baskı, Ebe İnsan Gücü Planlama Grubu Çalıșma Raporu, 6.

8. Yılmaz, T. ve Karanisoğlu, H. (2016). Türkiye'de Ebelik Eğitiminin Güncel Durumu. HSP, 3 (1), 73-7. Doi: $10.17681 / \mathrm{hsp} .32896$

9. Hotcourses. (2011). Yurtdışı Ebelik Doktora Ders Programları,

http://www.hotcoursesTurkey.com/study/trainingdegrees/in ternational/phd/midwifery-courses/slevel/15/cgory/ph.53 4/sin/ct/page/2/programs.html

10. Yurtsal, B., Biçer, S., Duran, Ö., Şahin, A., Arslan, M., Yavrucu, Ö. K. (2014). Sağlık Bilimleri Ebelik 1. Ve 4. Sınıf Öğrencilerinin Mesleğe İlişkin Görüslerinin Belirlenmesi. Erciyes Üniversitesi Sağlık Bilim Fakültesi Dergisi, 2 (2), 13-6.

11. Karaçam, Z. (2016). Türkiye'de Profesyonel Bir Disiplin Olarak Ebelik Mesleğinin Durumu: Yasal Düzenlemeler, Eğitim ve Araștırma, Lokman Hekim Dergisi, 6 (3), 128-36.

12. Kuruthan, M. N. \& Oran, F. (2018). Harita Prensiplerinin Görsel Haritalama Tekniğine Göre Bibliyometrik Analizi. Sage Yayıncılık San. Tic. ve Ltd. Şti. 1. Basım, Ankara, ss:7-14.

13. Zupic, I. (2015). Bibliometricmethods İn Management And Organization. Organizational Research Methods, 18 (3), 429-72.

14. Kantek, F. \& Yessilbas, H. (2018). Bıblıometrıc Analysıs Of Problem Solving Literature In Nursing Students: The Case Of Turkey, Journal of Educational \&Instructional Studies in the World, 8, 28-34.

15. Kurutkan, M. N., Orhan, F. \& Kaygısız, P. (2017). Hasta Güvenliği Literatürünün Bibliyometrik Analizi: Türkçe Tez ve Makaleler Örneği, 4 (4), 253-57. do1:10.5455/sad.131513948006.

16. Aydın, B. (2017). Yükseköğretim Kurulu Tez Merkezinde (Yöktez) Yiyecek İçecek İşletmeciliği Alanında Kayıtlı Bulunan Tezlerin Bibliyometrik Analizi, Disiplinler aras Akademik Turizm Dergisi, 2 (1), 23-38.
17. Gündüz, M. (2018). Türkiye'de 2014-2016 Yilları Arasında Akademik Dergilerde Muhasebe Alanında Yayınlanan Makalelerin Bibliyometrik Analizi, Muhasebe Bilim Dünyası Dergisi, 20 (1), 236-57.

18. Temizkan, S. P., Dönüş, Ç. \& Özdemir, C. (2015). Sağlık Turizmi Konusunda Yayınlanan Makalelerin Bibliyometrik Profili, International Journal of Human Sciences, 12 (2), 394-415.

19. Davidson, P. M., Newton, P. J., Ferguson, C., Daly, J., Elliott, D., Homer, C., Duffield, C. \& Jackson, D. (2014). Rating and Ranking the Role of Bibliometrics and Webometrics in Nursing and Midwifery. Scientific World Journal, 3- $\quad 6 \quad$ Article 135812.http://dx.doi.org/10.1155/2014/135812

20. Polat, C., Sağlam, M. \& Sarı, T. (2013). Atatürk Üniversitesi İktisadi ve İdari Bilimler Dergisi'nin Bibliyometrik Analizi. Atatürk Üniversitesi İktisadi ve İdari Bilimler Dergisi, 27 (2), 273-88.

21. Thelwall, M. (2008). Bibliometrics to Webometrics, Journa of Information Science, 34 (4), 605-621.

22. Çetinkaya, B. Ö. \& Çetin, A. (2016). Girişimcilik ve Kalkınma Dergisi'nin Bibliyometrik Analizi, Girişimcilik ve Kalkınma Dergisi, 11 (2), 229-63.

23. Smith, D. R. (2010). A Longitudinal Analysis of Bibliometric and İmpact Factor Trends Among The Core International Journals of Nursing, 1977-2008, International Journal of Nursing Studies, 47 (12). 1491-99.

24. Shelton, R. D. \& Leydesdorff, L. (2012). Publish Or Patent: Bibliometric Evidence for Empirical Trade-Offs in National Funding Strategies, Journal of the American Society for Information Science and Technology, 63 (3), 498-511.

25. Tel, H. \& Sabancıoğulları, S. (2014). Psikiyatri Hemsireliğ Doktora Tezlerinin Özellikleri. Dokuz Eylül Üniversitesi Hemşirelik Fakültesi Elektronik Dergisi, 7 (3), 178-85.

26. Creswell, JW. (2017). Araștırma Deseni, Çeviri Edit: Demir, B Ş. Girişim matbaacılık, 3. Baskı, Ankara, 13-19.

27. Öncel, S. \& Sümen, A. (2017). Türkiye'de Halk Sağlığ Hemsireliği Alanında Yürütülen Lisansüstü Tezlerin Değerlendirilmesi, Türkiye Klinikleri J Public Health NursSpecial Topics, 3 (1), 20-8.

28. Özsoy, S., Yıldırım, J. G., Kalkım, A., Muslu, L. \& Yıldırım, N. (2012). Türkiye'de Hemşirelikte İş Sağlığı Lisansüstü Tezlerinin Eleștirel Değerlendirmesi. Ege Üniversitesi Hemşirelik Fakültesi Dergisi, 28(3), 65-84.

29. Dönmez, Y. C., Soyer Geçkil, Ö., Yavuz Van Giersbergen, M. (2018). Türkiye'de Yapılan Cerrahi Hastalıkları Hemşireliği Doktora Tezlerinin İncelenmesi (1991-2015). Koç Üniversitesi Hemşirelikte Eğitim ve Araștırma Dergisi (HEAD), 15 (4), 248-55. Do1:10.5222/HEAD.2018.248.

30. Aytaç, S., Madenoğlu Kıvanç, M. \& Ay, F. (2014). Dört Avrupa Ülkesinde Ebeliğin Güncel Durumu ve Ebelik Araştırmalarının Gelişimi. Sağlık Bilim ve Meslekleri Dergisi, 1 (1), 77.

31. Ciçek Okuyan, Y., Tuna Oran, N. ve Öztürk Can, H. (2019). Ebelik Uygulama Alanlarında Yapılan Teori ve Modele Dayalı Tezler, Life Sciences (NWSALS), 14 (1):20-29, Do1: 10.12739/NWSA.2019.14.1.4B0022.

32. Ege Üniversitesi, Yüksek Lisans Programları Program Tanımları,

Kurulus, https://ebys.ege.edu.tr/ogrenci/ebp/organizasyon.aspx?kultur=tr -tr\&Mod=2\&ustbirim=193\&birim=56\&altbirim=-

$1 \&$ program $=4413 \&$ organizasyonId $=60084 \&$ mufredatTurId=93 2001.Erişim Tarihi:21.02.2019. 